\title{
Celebrity Endorsement Advertising: Brand Awareness, Brand Recall, Brand Loyalty as Antecedence of South African Young Consumers' Purchase Behaviour
}

\author{
Thubelihle Ndlela, *Tinashe Chuchu \\ University of the Witwatersrand, South Africa \\ tinashe.chuchu@wits.ac.za
}

\begin{abstract}
Celebrity endorsement advertising has received much attention in recent years from marketing practitioners and academic researchers. Pepsi spent $\$ 50$ million dollars on an endorsement contract with Beyoncè Knowles which accounted for a sixth of the company's total budget. This research paper aims to examine whether or not South African marketers can utilise celebrity endorsements to promote their products or brands to young consumers effectively. The other purpose of this study is also to establish whether brand recall, brand awareness, brand loyalty and purchase behaviour are positively influenced by celebrity endorsement advertising. Utilising a quantitative research approach a field study was conducted in Durban whereby research data was collected from 325 participants 18 to 24 years of age. The research survey comprised of 25 questions that were self-administered to willing participants over a one month period. Using SPSS 23 and AMOS 23 software programs, Structural Equation Modeling (SEM) was performed to analyze the data set. Major findings revealedthat brand loyalty is the most significant antecedent of purchase behaviour. Furthermore the study also revealed that participants in the 18-20 year age group were more inclined towards purchasing and paying more for celebrity endorsed brands as compared to any other age group in the survey.Lastly this study provides marketing practitioners an understanding of how firms can benefit from the use as it was found that brand recall and brand loyalty positively influence purchase behaviour whilst brand awareness had no direct influence on purchase behaviour.
\end{abstract}

Keywords: Celebrity endorsement, purchases, brands, advertising

\section{Introduction}

Han, Rashad and Yazdanifard (2015) refer to celebrity advertising as the use a famous person's image to sell products or services by embracing the individual's wealth, popularity, or fame to endorse the products or services. The specific purpose of this research paper is to establish the influence of celebrity endorsement advertising on young South African consumers. Approximately 20-25\% of advertisements feature a famous person as an endorser (Sliburyte, 2009). Advertising has infiltrated every part of our day-to-day lives. Each day, consumers are exposed to more than 1,500 advertising messages from a variety of sources namely television, billboards, radio, flyers enclosed with credit card and utility bills, mobile phones, the grocery store floor, and even public restrooms (Koernig \& Boyd, 2009). A commonly used strategy to slice through this advertising clutter is to include celebrity endorsers in advertisements (Koernig \& Boyd, 2009). Celebrity endorsement advertising appears to be a new trend but it actually dates back to the $19^{\text {th }}$ century when British actress Lillie Langtry appeared on a Pears soap commercial proving that this is a culture that is engrained in society (Han et al., 2015). Barnes (2011) and Han et al. (2015) postulate that celebrity advertising influences consumer purchases in allowing the consumer to think that products will work for them as they did for a celebrity. Notwithstanding the popularity of celebrity endorsement as a modern advertising strategy its profitability and marketing effectiveness has garnered considerable interest (Sheu, 2010). Furthermore, the exorbitant annual advertising budgets that are set aside for endorsement deals, especially by multinationals and other local South African companies such as Unilever, Proctor and Gamble and Nike motivates the need to evaluate endorser's financial effects on the organisation and consumer brand attitudes.

Celebrity is a means of brand communication whereby the celebrity acts as a brand's spoke's person and endorses a brand's claims and position by spreading his or her personality, popularity and status in the field of the brand (Sajan \& Nerhu, 2014). Celebrity endorsement has the influence to initiate, arouse, inform, infuriate, amuse and inform the consumer (Sajan \& Nerhu, 2014). Celebrity endorsement is highly regarded 
as a lucrative promotional tool for advertisers' brands and services (Patel, 2009). However, there is minimal evidence that a celebrity advertising strategy influences or affects consumer brand attitudes such as purchase behaviour amongst young consumers in South Africa. This study will thoroughly examine this advertising strategy. Companies invest large sums of money to align their brands and themselves with endorsers (Rawtani, 2010). In fact, such enormous investments benefit brand managers if they translate into favourable brand recall as compared to a similar advert that features an unknown endorser (Erfgen, Zenker \& Sattler, 2015). Such endorsers are seen as dynamic, with both attractive and likeable qualities and companies hope that these qualities will be transferred to their products. Due to their fame, celebrities serve not only to create and maintain attention but also to achieve high recall rates for advertising messages in today's highly brand saturated environments (Rawtani, 2010).

This study aims to ascertain if utilising such a costly advertising strategy is justified in South Africa. The current popularity of celebrity endorsements can be attributed to the numerous benefits retailers see in utilising this form of advertisement (White, Godard \& Wilbur, 2009). For example, celebrities who are featured as endorsers have the ability to grab the audience's attention, giving retailers a better chance of communicating their message to consumers (White et al., 2009). Specifically, this study seeks to establish the effectiveness of the use the celebrity advertising strategy as a promotional tool for advertisers. Furthermore, to investigate to what extent it influences brand attitudes and purchase intention in a South African context. There is a need for insightful research on celebrity endorsement advertising in South Africa, for example, exploring innovative ways to better ensure that organisations attain good returns on their investment whilst fulfilling their advertising objectives such as brand awareness, brand memorability and purchase behaviour. Overall, this study makes several contributions to literature specifically adding to the body of knowledge surrounding the use of celebrity endorsements in advertising, consumer behaviour and branding in South Africa.

\section{Literature Review}

The review of literature plays a crucial role in the current research. In this section efforts are directed to explore or assess the findings of the studies conducted by various scholars in the same field.

Theory of Planned Behaviour: The theory of planned behaviour (TPB) is a theory intended to predict and explain human behaviour in precise situations (Ajzen, 1991). The TPB was adopted and deemed appropriate for the current study as it focuses on purchase of behaviour and attitudes of consumers. The TPB has arose as one of the most influential and prominent conceptual frameworks for the study of human action (Ajzen, 2002). Conner and Armitage (2001) pointed out that the theory of planned behaviour (TPB) is essentially an extension of the theory of reasoned action (TRA) that includes measures of control belief and perceived behavioural control.It predicts the occurrence of a specific action provided that the action is intentional (Francis, Eccles, Johnston, Walker, Grimshaw, Foy, Kaner, Smith \& Bonetti, 2004).The theory of planned behaviour emerged about due to the fact that the theory of reasoned action had limitations in its model when dealing with behaviours over which people have incomplete voluntary control (Ajzen, 1991). Henle, Reeve \& Pitts (2010) pointed out that when individuals have a stronger motivation or intention to engage in a particular behaviour, the TPB proposes that individuals are more likely to follow through with that behaviour. Francis et al. (2004) pointed out that in order to predict whether an individual intends to do a particular act, there is need to know: whether that individual is inclined towards performing that particular act, how much the individual feels social pressure to do it and whether the individual feels in control of the action in question.

Celebrity Endorsement Advertising: Endorsement occurs when a celebrity lends his/her name to and appears on behalf of a product or service on which he or she may or may not be an expert (Bekk \& Spörrle, 2010). Celebrity endorsement advertising can be executed in different ways. For example, a celebrity can casually appear in the advert or commercial using the manufacturer's product or brand. In other instances a celebrity may give a testimonial about a brand's features and benefits and recommend that consumers use it. In addition, some celebrity endorsements involve celebrities giving expert opinions, being a spokesperson for a product or just being associated with the product. Celebrities as part of a marketing communications strategy is a fairly common marketing practice for major firms in supporting corporate and brand imagery 
(Erdogan, Baker \& Tagg, 2001). Celebrity endorsements have been growing consistently since the 1970s (Costanzo \& Goodnight, 2006). Choi and Rifon (2007) point out that American society today is to be fascinated by celebrities. Many successful individuals from a variety of fields, ranging from entertainment to sport, to cuisine, business and politics are elevated to celebrity status (Choi \& Rifon, 2007).

Brand Awareness: Brand awareness refers to the ability of consumers to recall or recognise a brand, or simply whether or not consumers know about a brand (Keller, 2008). According to Berry (2000) brand awareness is the customer's ability to identify and remember the brand when provided a cue. Furthermore brand awareness offers a sort of learning advantage for the brand (Keller, 2008). Brand awareness influences consumer decision-making, especially for low-involvement packaged goods. Brands that consumers are familiar with are likely to be included in the consumers' consideration set (Macdonald \& Sharp, 2000; Huang \& Sarigöllü, 2012). Brand awareness can be used by consumers as a purchase decision heuristic (Macdonald \& Sharp, 2000; Huang \& Sarigöllü, 2012). Therefore, brand awareness increases brand market performance.

Brand Recall: Brand recall is the consumer's ability to remember a brand when given the product category whilst brand recognition refers to a consumer's ability to identify a brand when given the brand name as a clue (Lu, Chang and Chang, 2014). Illicic \& Webster (2011) pointed out that celebrity endorsement focuses on how specific celebrity characteristics influence the consumer's evaluations and recall if advertising as well as the featured products and brands. The use of celebrity endorsements can improve advertising recall rates (Ilicic \& Webster, 2011). Hudders, Cauberghe, Panic, Faseur and Zimmerman(2012) found that the extent of a brand's prominence positively affects the extent to which that brand is recalled, regardless of the extent to which that respondent is connected to the artist endorsing the brand. Hudders et al. (2012) add that prior research has revealed that prominent placements indeed draw more attention to the placed brand and therefore lead to greater recall and recognition than regular placements.

Brand Loyalty: Belaid and Behi (2011) state that brand loyalty can be regarded as the consumers' repetitive and systematic purchase of the same brand. Liu, Li, Mizerki and Soh (2012) posit that for real brand loyalty to be present, consumers must be emotional attached to the brand and be prepared to make sacrifices for this attachment (Tsai, 2011). Rauyruen and Miller (2007) point out that brand loyalty is motivated principally by the sense of attachment linking buyers to their supplier(s), and secondarily by rational and normative intentions. Illicic and Webster (2011) stated that that past research has established that a greater degree of satisfaction leads to a greater degree of loyalty. However Petzer, Mostert, Kruger and Kuhn (2014) argue that satisfaction on its own does not necessarily lead to brand loyalty. Biscaia, Correia, Rosado, Ross and Maroco (2013) posit that behavioral loyalty has a direct positive effect on attitude towards actual sponsors

Figure 1: The Proposed Research Conceptual Model

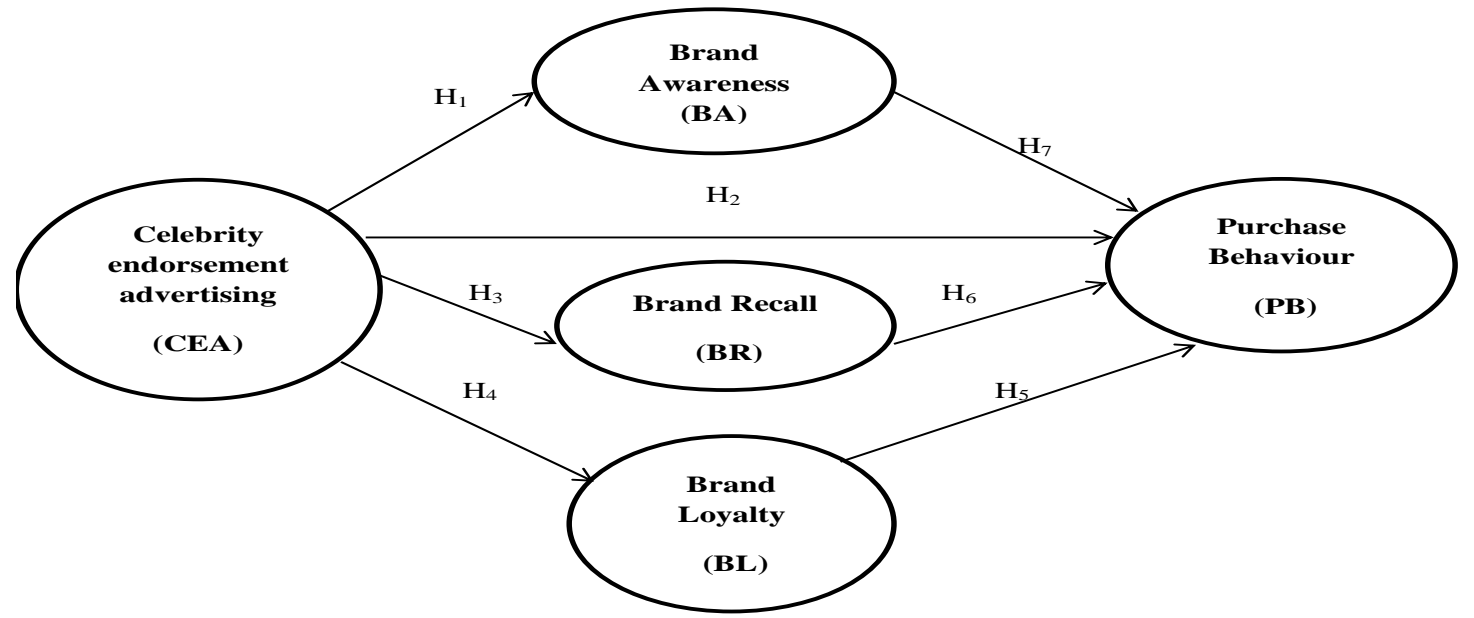

Purchase Behaviour: Understanding the ways in which consumers' involvement levels influence how they use different cues to make purchase decisions has been a topic of research for several decades (Hollebeek, Jaeger, Brodie \& Balemi, 2007). According to Akehurst, Afonso and Goncalves (2012) consumer behaviour is 
also influenced by concerns about the brand, culture, demographic characteristics, finance, behaviours, lack of information, lifestyles, personalities or moral issues. However according to a study by Tan (2002), in which 377 Chinese software users where interviewed, it was established that purchase behaviour is influenced by; the perceived moral intensity; degree of consequences; temporal use and social risk; the perceived commercial performance; and prosecution and moral judgment.

Proposed Conceptual Model and Research Hypotheses: The proposed conceptual model below in figure1consists of one predictor variable Celebrity endorsement advertising (CEA), three mediator variables brand awareness (BA), brand recall (BR) and brand loyal (BL) and the outcome variable purchase behaviour (PB). An illustration of the conceptual model is provided above page.

Hypothesis Development: The proposed conceptual model consists of the predictor variable celebrity endorsement advertisement, three mediator variables (brand awareness, brand recall and brand loyalty) and the outcome variable (purchase behaviour). The proposed conceptual model displaying all of the hypothesized relationships is presented in Figure 1. Individual hypotheses are developed and discussed next.

\section{H1: Celebrity endorsement advertising is positively related to brand awareness}

Celebrity refers to a notable personality (Muda, Musa and Putit, 2012). According to Ranjbarian, Shekarchizade and Momeni (2010), a celebrity endorser is a well-known person due to his or her successes in a field other than the endorsed product class. An endorser is a person who makes a testimonial, or a written or spoken statement, extolling the virtue of a product (Rodriguez, 2009). This person could be a public figure or a private citizen. (Rodriguez, 2009) stated that, a testimonial usually applies to sales pitches attributed to ordinary citizens, whereas endorsement usually applies to pitches by celebrities. Brand awareness refers to whether consumers can recall or identify a brand, or merely whether or not consumers know about a brand (Keller, 2008). Brand awareness and perceived quality are generally perceived as stocks that are built up over time in response to advertising (Clark, Doraszelski \& Draganska, 2009). Macdonald and Sharp (2000) state that consumers have a strong tendency to rely on brand awareness when selecting a product because consumers will feel that a renowned brand is more reliable than an unknown brand. Celebrity endorsers have been utilised in advertising not simply to attract attention of audiences, but also to escalate message persuasiveness, thereby enhancing advertising effectiveness (Muda et al., 2012). Therefore, inferring from the literature and the empirical evidence abovementioned, the study hypothesizes that:

$\mathrm{H}_{1}$ : celebrity endorsement advertising has a positive relationship with brand awareness

\section{H2: Celebrity endorsement advertising is positively related to purchase behaviour}

Prior research has demonstrated that consumer's evaluations in terms of attitudes towards the advert, attitude towards the brand and purchase intention are greater when a celebrity endorses a brand (Illicic \&Webster, 2011).A number of researchers found that the celebrity's credibility is a much more significant factor in explaining consumers' purchase intentions than the celebrity's attractiveness(Dix, Phau \& Pougnet, 2010). Sport celebrities for example have been established as viable and influential role models for young people, playing an important part in the consumer socialization process, and it is expected that they would influence young adult's buyer intentions and behaviour (Dix et al., 2010). However, for sports celebrity endorsers to be persuasive in influencing purchase intention, there should be celebrity- product- match and the celebrity should be regarded as an expert in the product category (Dix et al., 2010). Biscaia et al. (2013) suggested that attitudes towards sponsor have a positive and direct influence on purchase intention.Therefore, inferring from the literature and the empirical evidence abovementioned, the study hypothesizes that:

$\mathrm{H}_{2}$ : celebrity endorsement advertising has a positive relationship with purchase behaviour

\section{H3: Celebrity endorsement advertising is positively related to brand recall}

Brand recall, is defined as the consumer's capacity to recall and recognise the brand (Malik \& Sudhakar, 2014). Empirical studies in the area of celebrity endorsement focus on how specific celebrity characteristics influence consumer's evaluations and recall if advertising as well as the featured products and brands (Illicic \&Webster, 2011). Most marketers justify the enormous amounts budgets on celebrity endorsements since it is believed that celebrities make advertisements attractive and enhance message recall thereby engaging potential consumers and aiding brand marketing (Sheu, 2010). Moreover, celebrity endorsers create 
attention, maintain attention and also achieve high recall for the stigma because of their fame in today's highly cluttered marketing communications environment (Malik \& Sudhakar, 2014). Therefore, inferring from the literature and the empirical evidence abovementioned, the study hypothesizes that:

$H_{3}$ : celebrity endorsement advertising has a positive relationship with brand recall

\section{H4: Celebrity endorsement advertising is positively related to brand loyalty}

Brand loyalty has attracted much attention in recent years as brands are increasingly regarded as a means to meet the challenge of building lasting relationships with customers in business-to-business markets (Pedeliento, Andreini, Bergamaschi \& Salo, 2015). Prior studies provided evidence that brand loyalty is driven predominantly by the sense of attachment linking buyers to their supplier(s), and secondarily by rational and normative intentions (Rauyruen \& Miller, 2007). Celebrity endorsers are thought to help in the brand recognition and to establish both positive attitude and a distinct personality for the endorsed brand (Ding, Molchanov \& Stork, 2011).Many consumers aspire to share values and lifestyle of celebrities as models of success as they imitate and even impersonate celebrities' behaviour to enhance their own self-esteem (Alsmadi, 2006; Muda, Musa \& Putit, 2012). Therefore, inferring from the literature and the empirical evidence abovementioned, the study hypothesizes that:

$H_{4}$ : celebrity endorsement advertising has a positive relationship with brand loyalty

\section{H5: Brand loyalty is positively related to purchase behaviour}

Brand loyalty has attracted much attention in recent years as brands are increasingly regarded as a vehicle to meet the challenge of building lasting relationships with customers in business-to-business markets (Pedeliento et al., 2015). Since consumers identify with celebrities on several levels, marketers have an opportunity to associate consumers with product quality and or corporate reputation through celebrity endorsement (Petty \& D’Rozario, 2009) and gain a competitive advantage in specific markets(Wee \& Ming, 2003) through conveying product imagery to consumers(Kim, Lee \& Prideaux, 2014). The ability of celebrity to sell a product or service they endorse together with that celebrities worth to a firm is a function of the level of appeal he or she has to specific markets (Petty \& D'Rozario, 2009). Chi, Yeh and Yang (2009) argue that brand loyalty mediated the relationship between brand awareness and purchase behaviour. This implies that brand loyalty directly and positively influenced brand loyalty which in-turn led to purchase behaviour.Therefore, inferring from the literature and the empirical evidence abovementioned, the study hypothesizes that:

$H_{5}$ : Brand loyalty has a positive relationship with purchase behaviour

\section{H6: Brand recall is positively related to purchase behaviour}

Brand recall is defined as the consumer's ability to remember a brand when given the product category whilst brand recognition refers to a consumer's ability to identify a brand when given the brand name as a clue ( $\mathrm{Lu}$, Chang \& Chang, 2014). Celebrity endorsement is believed to create brand equity, enhance brand recall and other branding constructs (Illicic \& Webster, 2011). Illicic and Webster (2011) found that a celebrity endorser who is perceived to be an expert is found to be more persuasive and highly likely to generate greater intentions to buy a brand. Similarly, there is general consensus that credible endorsers can produce more favourable attitudes toward the advertisement and the intent to purchase a product (Wei \& Lu, 2013).Therefore, inferring from the literature and the empirical evidence abovementioned, the study hypothesizes that:

$H_{6}$ : brand recall has a positive relationship with purchase behaviour

\section{H7: Brand awareness is positively related to purchase behaviour}

Brand awareness can be used to measure the effectiveness of brand communication (Malik \& Sudhakar, 2014). Moreover, brand awareness affects perceptions, attitudes of the customers and it also reflects the salience of the brand in the customers mind (Malik \& Sudhakar, 2014). If consumers are knowledgeable about a specific brand, regardless of this knowledge being actively or inactively obtained, their brand awareness toward a certain product or service is high (Valkenburg \& Buijzen, 2005; Lu, Chang \& Chang, 2014). Prior studies reveal that if consumers are more familiar with a brand they will be more likely to trust in that brand (Lu, Chang \& Chang, 2014). Therefore, inferring from the literature and the empirical evidence abovementioned, the study hypothesizes that:

$H_{7}$ : brand awareness has a positive relationship with purchase behaviour 


\section{Methodology}

Research Design: The study utilised the positivist paradigm, a philosophy that is of the view that knowledge stems from human experience (Collins, 2010). A quantitative research approach was adopted for this study whereby a 25 question survey was self-administered to 325 willing participants in Durban, South Africa. Simple random sampling, a form of probability sampling was adopted in selecting participants with the sole purpose of providing every unit within the population an equal chance to be sampled as suggested by (Galpin, 2011; Daniel, 2011).

Measurement Instruments: The research constructs were adapted from prior studies of the same research area. Adequate adaptations were made to the research constructs so as to accommodate the current study's context and purpose. A five-item Likert scale anchored by $1=$ strongly agree to $5=$ strongly disagree. Individual scale items are listed in the Appendix.

Survey Design: In any study the theoretical constructs that are measured are the determining factors for the choice of measurement methodology (Fagarasanu \& Kumar, 2002). The primary data collection instrument used for this research was a research questionnaire. The questionnaire comprised of five sections A, B, C, D, E and F. Section A represented the respondent's biographical information such as gender and age. Sections B, C, $\mathrm{D}$ and $\mathrm{E}$ utilised a 5 point likert scale to ask the respondents questions that were based on the research model. Section B asked the respondent questions regarding Celebrity Endorsement Advertising (CEA). Section C asked about Brand Awareness (BA). Section D asked about Brand Recall (BR). Section E asked about Purchase behaviour and finally Section E asked about Brand Loyalty. The questionnaire was designed based on the study's research model. A total of 325 questionnaires were collected and used for data analysis.

\section{Data Analysis and Results}

Sample Description: Table 1 presents the profile of the participants. The profile indicates that the proportion of males to females. Males represent $26.8 \%$ of the total sample and females represent $73.2 \%$. Most of the respondents were in the $18-20$ year age category and represented $48.3 \%$ and the age group with the least number of respondents was the 24 year age group representing 8 percent of the total sample. Most of the respondents chose L'OREAL advertised by Terry Phetho as their preferred brand and this was indicated by $32.3 \%$ of the total sample and the least preferred brand was Shield body spray advertised by Lira indicated by $12.3 \%$ of the total sample. Table 1 illustrated in the following section presents a profile of the participants.

Table 1: Sample Demographic Profile

\begin{tabular}{lll}
\hline Gender & Frequency & Percentage \\
\hline Male & 87 & $26.8 \%$ \\
Female & 238 & $73.2 \%$ \\
& 325 & $100 \%$ \\
Age & & \\
$18-20$ & Frequency & Percentage \\
$21-23$ & 157 & $48.3 \%$ \\
24 & 142 & $43.7 \%$ \\
& 26 & $8 \%$ \\
Respondents' choice of brands and & Frequency & $100 \%$ \\
celebrities & & \\
Garnier Oil Control: Zizo Beda & 89 & Percentage \\
L'OREAL: Terry Phetho & 105 & \\
Vaseline Men: ItumelengKhune & 42 & $27.4 \%$ \\
Status body spray: HHP & 60 & $32.3 \%$ \\
Shield body spray: Lira & 40 & $13.8 \%$ \\
& 325 & $18.5 \%$ \\
\hline
\end{tabular}


Scale Accuracy Analysis: The scale construct correlations are presented in Table 2, the mean scores of scales and their corresponding scale items are presented in Table 3. Individual scale item test summaries related to research scale reliability and validity are explored thereafter. The results of scale reliability tests are shown in Table 3. As can be seen, item-to-total values ranged from 0.663 to 0.881 , while Cronbach's alpha coefficients ranged from 0.871 to 0.932 and composite reliability (C.R.) indexes were between 0.852 and 0.953 . These values exceeded the estimate criteria used by previous literature. Average variance extracted (AVE) values ranged from 0.718 and 0.882 exceeding the recommended 0.7 thus marginally accepted according to the (Fraering \& Minor, 2006). These results provided proof of marginal to acceptable levels of research scale reliability and validity. The scale validity was investigated mainly utilising a confirmatory factor analysis (CFA) while all scale items were joint. The results are illustrated in Tables 2 and 3. Convergent validity was tested by evaluating whether the path coefficients (loadings) between each latent construct and its corresponding scale items were statistically significant. Most of the factor loadings in the CFA were significant (between 0.6 and 0.9), confirming the convergent validity of all scale items. The measurement model produced a ratio of chi-squared value over degree-of-freedom of 2.384, and GFI, CFI, IFI, TLI, RFI, NFI and RMSEA were $0.911,0,966,0,947,0,966,0,912,0,943$ and 0,065 respectively.The above results indicated that the research scales decisively encompassed distinct components, thus supporting discriminant validity of the research constructs.

Proposed Conceptual Model Fit Assessments: The evaluation of the proposed conceptual model proceeded utilising the same data set. The following model fit measures were used to assess the reliability and validity of the data. The ratio of chi-squared over degree-of-freedom was 2,384. Additional GFI, CFI, IFI, TLI, RFI, NFI and RMSEA values were $0.911,0,966,0,947,0,966,0,912,0,943$ and 0,065 respectively.All model fit measures exceeded recommended thresholds, which posited that the proposed conceptual model converged well and could be a plausible representation of the underlying empirical data structure collected. The corresponding coefficients of the research hypotheses that suggested the existence of positive relationships between all relationships with the exception of brand awareness and brand preference $\left(\mathrm{H}_{7}\right)$ were then observed. Accuracy analysis statistics are illustrated in table 3 below. Table 2 below illustrates correlations between research constructs.

Table 2: Correlations between Constructs

\begin{tabular}{llllll}
\hline & CEA & BA & BR & PB & BL \\
\hline CEA & 1 & & & & \\
BA & $0.311^{* *}$ & 1 & & & \\
BR & $0.141^{*}$ & $0.609^{* *}$ & 1 & & \\
PB & 0.029 & $0.229^{* *}$ & $0.658^{* *}$ & 1 & \\
BL & 0.044 & $0.187^{* *}$ & $0.395^{* *}$ & $0.637^{* *}$ & 1 \\
\hline
\end{tabular}

**. Correlation is significant at the 0.01 level (2-tailed).

*. Correlation is significant at the 0.05 level (2-tailed).

As observed in Table 2 above all correlation values range from 0.044 to 0.311 . Most of the correlation values were significant at both 0.01 and $0.05 \mathrm{p}$ value level of significance. Discriminant validity of the research constructs was assessed using correlations among latent constructs of less than 1.0. Table 3 below illustrates descriptive and reliability statistics. 
Table 3: Descriptive and Reliability Statistics

\begin{tabular}{|c|c|c|c|c|c|c|c|c|c|c|c|}
\hline \multirow{2}{*}{\multicolumn{2}{|c|}{$\begin{array}{l}\text { Research } \\
\text { Construct }\end{array}$}} & \multicolumn{4}{|c|}{ Descriptive Statistics } & \multicolumn{2}{|c|}{$\begin{array}{l}\text { Cronbach's } \\
\text { Test }\end{array}$} & \multirow[t]{2}{*}{ C.R. } & \multirow[t]{2}{*}{$\overline{\text { AVE }}$} & \multirow[t]{2}{*}{ HSV } & \multirow[t]{2}{*}{$\begin{array}{l}\text { Factor } \\
\text { Loading }\end{array}$} \\
\hline & & \multicolumn{2}{|c|}{ Mean Value } & \multicolumn{2}{|c|}{$\begin{array}{l}\text { Standard } \\
\text { Deviation }\end{array}$} & \multirow{2}{*}{$\begin{array}{l}\begin{array}{l}\text { Item- } \\
\text { total }\end{array} \\
0,747\end{array}$} & $\alpha$ & & & & \\
\hline \multirow{5}{*}{ BL } & BL1 & 3,649 & 3,581 & 0,790 & 0,796 & & 0,932 & 0,953 & 0,882 & 0,406 & 1,031 \\
\hline & BL2 & 3,569 & & 0,793 & & 0,881 & & & & & 0,924 \\
\hline & BL3 & 3,588 & & 0,810 & & 0,840 & & & & & 0,869 \\
\hline & BL4 & 3,557 & & 0,790 & & 0,879 & & & & & 0,897 \\
\hline & BL5 & 3,542 & & 1,795 & & 0,760 & & & & & 0,739 \\
\hline \multirow[t]{5}{*}{$\mathrm{BP}$} & BP1 & 3,668 & 3,601 & 0,790 & 0,831 & 0,697 & 0,896 & 0,884 & 0,730 & 0,433 & 0,734 \\
\hline & BP2 & 3,640 & & 0,829 & & 0,805 & & & & & 0,849 \\
\hline & BP3 & 3,655 & & 0,808 & & 0,824 & & & & & 0,791 \\
\hline & BP4 & 3,449 & & 0,920 & & 0,678 & & & & & 0,671 \\
\hline & BP5 & 3,594 & & 0,810 & & 0,730 & & & & & 0,835 \\
\hline \multirow[t]{4}{*}{ BR } & BR1 & 3,640 & 3,662 & 0,803 & 0,804 & 0,722 & 0,894 & 0,852 & 0,718 & 0,433 & 0,838 \\
\hline & BR2 & 3,649 & & 0,820 & & 0,802 & & & & & 0,742 \\
\hline & BR3 & 3,686 & & 0,809 & & 0,812 & & & & & 0,742 \\
\hline & BR4 & 3,674 & & 0,785 & & 0,730 & & & & & 0,749 \\
\hline \multirow[t]{5}{*}{ BA } & BA1 & 3,508 & 3,567 & 0,748 & 0.778 & 0,663 & 0,908 & 0,894 & 0,749 & 0,371 & 0,619 \\
\hline & BA2 & 3,545 & & 0,783 & & 0,789 & & & & & 0,763 \\
\hline & BA3 & 3,578 & & 0,792 & & 0,831 & & & & & 0,829 \\
\hline & BA4 & 3,628 & & 0,758 & & 0,829 & & & & & 0,916 \\
\hline & BA5 & 3,578 & & 0,811 & & 0,737 & & & & & 0,815 \\
\hline \multirow[t]{3}{*}{ CEA } & CEA1 & 3,640 & 3,568 & 0,730 & 0,744 & 0,785 & 0,871 & 0,870 & 0,810 & 0,097 & 0,878 \\
\hline & CEA2 & 3471 & & 0,731 & & 0,707 & & & & & 0,756 \\
\hline & CEA3 & 3594 & & 0,771 & & 0,770 & & & & & 0,855 \\
\hline
\end{tabular}

CR: composite reliability; AVE: average variance extracted; HSV: highest shared variance;

${ }^{\text {a }}$ significance level $p<0.05$; ${ }^{\text {b }}$ significance level $p<0.01$; $^{\mathrm{c}}$ significance level $p<0.001$.

As can be seen it table 3 above all the mean values range from 3.449 to 3.668, standard deviations range from 0.730 to 0.920 . The item to total values ranged from 0.678 to 0.881 . The composite reliability (CR) values range from 0.852 to 0.953 whilst the average variance extracted (AVE) values range from 0.718 to 0.882 . Most of the factor loadings are above 0.671. It can also be observed that there is evidence of discriminant validity as the average variance extracted values are greater than the highest shared variance values.

Path Modeling \& Hypotheses Testing: Table 4 presents the results of the structural equation modeling followed by a discussion 
Table 4: Results of Structural Equation Model Analysis

\begin{tabular}{|c|c|c|c|c|}
\hline Proposed relationship hypothesis & Hypothesis & $\begin{array}{l}\text { Factor } \\
\text { Loading }\end{array}$ & $\begin{array}{l}\mathbf{P} \\
\text { Value } \\
\end{array}$ & $\begin{array}{l}\text { Supported/ } \\
\text { Rejected }\end{array}$ \\
\hline $\begin{array}{l}\text { Celebrity Endorsement Advertising (CEA) Brand } \rightarrow \\
\text { Awareness (BA) }\end{array}$ & $\mathrm{H}_{1}$ & $0.32^{\mathrm{b}}$ & $* * *$ & $\begin{array}{l}\text { Supported and } \\
\text { significant }\end{array}$ \\
\hline $\begin{array}{lll}\text { Celebrity } & \text { Endorsement } & \text { Advertising } \rightarrow \\
\text { (CEA)Purchase Behaviour (PB) } & \end{array}$ & $\mathrm{H}_{2}$ & $0.02^{b}$ & $* * *$ & $\begin{array}{l}\text { Supported and } \\
\text { significant }\end{array}$ \\
\hline $\begin{array}{l}\text { Celebrity Endorsement Advertising } \quad(\text { CEA }) \rightarrow \\
\text { Brand Recall (BR) }\end{array}$ & $\mathrm{H}_{3}$ & $0.18^{b}$ & $* * *$ & $\begin{array}{l}\text { Supported and } \\
\text { significant }\end{array}$ \\
\hline $\begin{array}{l}\text { Celebrity Endorsement Advertising } \quad \text { (CEA) } \rightarrow \\
\text { Brand Loyalty (BL) }\end{array}$ & $\mathrm{H}_{4}$ & 0.06 & 0,318 & $\begin{array}{l}\text { Unsupported and } \\
\text { insignificant }\end{array}$ \\
\hline Brand Loyalty(BR)Purchase Behaviour(PB) $\rightarrow$ & $\mathrm{H}_{5}$ & $0.67^{b}$ & $* * *$ & $\begin{array}{l}\text { Supported } \\
\text { significant }\end{array}$ \\
\hline Brand Recall(BL) Purchase Behaviour (PB) & $\mathrm{H}_{6}$ & $0.35^{b}$ & $* * *$ & $\begin{array}{l}\text { Supported and } \\
\text { significant }\end{array}$ \\
\hline Brand Awareness (BA)Purchase Behaviour (PB) $>$ & $\mathrm{H}_{7}$ & $-0.23^{b}$ & $* * *$ & $\begin{array}{l}\text { Unsupported but } \\
\text { significant }\end{array}$ \\
\hline
\end{tabular}

Structural model fits: $\chi^{2} / \mathrm{df}=2,384 ; \mathrm{GFI}=0.911 ; \mathrm{CFI}=0,966$; TLI= 0,947; IFI= 0,966; RFI= 0,912; NFI=0,943; RMSEA $=0,065$; ${ }^{\text {a }}$ significance level $\mathrm{p}<0.05$; $^{\mathrm{b}}$ significance level $<0.01$;

${ }^{\mathrm{c}}$ significance level<0.001

Discussion of Hypotheses Results: As illustrated in Figure 1, all hypotheses coefficients were at least at a significant level of $\mathrm{p}<0.01$. Therefore all the proposed hypotheses from H1 to H6 were all supported. Individual hypothesis coefficients between Celebrity Endorsement Advertising (CEA) and Brand Awareness (BA) (H1), Celebrity Endorsement Advertising (CEA) and Brand Preference (BP), (H2),Celebrity Endorsement Advertising (CEA) and Brand Recall (BR)(H3), Celebrity Endorsement Advertising (CEA) and Brand Loyalty (BL)(H4), Brand Recall (BR)and Brand Preference (BP) (H5), Brand Loyalty (BL) and Brand Preference (BP), Brand Loyalty (BL) and Brand Preference (BP) (H6), Brand Awareness (BA) and Brand Preference (BP) (H7) were 0.32; 0.02; 0.18; 0.06; 0.67; 0.35 and -0.23 .

Implications of the Study: The present study offers implications for marketing practitioners and academicians with regards to celebrity endorsement advertising. Based on the results of the current study brand loyalty is seen to have the strongest influence on purchase behaviour indicated by a path coefficient of 0.67 implying that marketing managers have to ensure that consumers are committed to a brand that a celebrity is endorsing in order to influence them the purchase that brand. As for academicians in the field of marketing this finding enhances their understanding of the relationship between brand loyalty and purchase behaviour as this is a useful contribution to existing literature on these to variables. It is also observed in the study that consumers 18 to 20 years of age are more likely to pay for celebrity endorsed brands and pay more than any other age group therefore implying that marketing practitioners should focus most, if not all of their efforts on targeting this age group with celebrity endorsement advertising. On the other hand the current study also reveals that brand awareness is inversely related to purchase behaviour implying that regardless of a consumer being aware of a brand it has no direct influence on that consumer actually purchasing that product and this is indicated by a negative path coefficient -0.23 . Therefore marketing managers must not sorely rely on consumers merely being aware of a brand as it has no direct influence on their purchase behaviour.

\section{Conclusion}

Based on the findings of the study it can be concluded that directly and positively affects, brand awareness, purchase behaviour, brand recall, brand loyalty. It is important to also note that brand awareness and purchase behaviour are negatively correlated implying that consumers merely knowing about a brand is not motivation enough for them to be loyal to that brand. It is observed that brand loyalty is the most influential 
antecedent of purchase behaviour implying that the extent to which consumers are loyal to a brand greatly determines their likelihood of purchasing the product advertised and is indicated by the highest factor loading which is 0.67 . This was indicated with a factor loading of $(0.32)$ which was higher than those of the other relationships. Furthermore, the study also found that participants in the 18-20 year age group were more likely to pay for celebrity endorsed brands than any other group at the same time also willing to pay for more for these brands than any other age group. It is also observed in the current study that advertising strategy influences consumers' brand attitudes such as brand recall, brand awareness, brand loyalty and purchase activity. However, the extent of this influence varies from one consumer to the next. It was also interesting to note that celebrity brand awareness was positively influenced purchase behaviour but did not influence brand loyalty as indicated by results of the study. It important to note that based on the findings of the study brand awareness was inversely related to purchase behaviour as indicated by a factor loading of (0.23) implying that regardless of consumers being knowledgeable about a brand that did not influence them to purchase it. It is important to note that a key finding of this study is that brand loyalty leads to purchase behaviour and this is supported by the finding of (Chi et al., 2009). The current study also found that brand awareness does not lead to purchase behaviour however interestingly this finding contradicts that of (Chi et al., 2009) which established that brand awareness directly leads to purchase behaviour. In conclusion, it is clear from the results of this study that celebrity endorsement affects consumer behaviour; however, the extent to which it does so depends on how well the marketing communications team executes the strategy in the relevant target market.

Suggestions for Future Research: The current study leaves room for further future research in the field of celebrity brand endorsements. There is an opportunity for researchers to either explore the same variables of this study in greater depth or to add new variables that could potentially predict purchase behaviour in relation to celebrity endorsements more accurately or differently. The author would recommend that similar studies as to the current study be conducted on a larger scale, that is a larger sample size, larger geographic regions and not limit the study to respondents of a certain demographic profile. For instance the current study only utilized respondents residing in one city and recommendations for future research would be for researchers to consider larger populations such as surveying respondents from more than one city or province. This would allow for more diversity in the sample and more informed results. The study suffered greatly from financial and time constraints and the researchers believe that if these challenges are addressed it would result in a more meaningful and superior contribution to the literature of celebrity endorsement advertising.

\section{References}

Ajzen, I. (1991). The theory of planned behavior. Organizational behavior and human decision processes, $50(2), 179-211$.

Ajzen. (2002). Perceived Behavioural Control, Self-Efficacy, Locus of Control, and the Theory of Planned Behaviour. Journal of Applied Social Psychology, 32(4), 665-683.

Akehurst, G., Afonso, C. \& M. Gonçalves, H. (2012). Re-examining green purchase behaviour and the green consumer profile: new evidences. Management Decision, 50(5), 972-988.

Alsmadi, S. (2006). The power of celebrity endorsement in brand choice behaviour: An empirical study of consumer attitudes in Jordan. Journal of Accounting - Business \& Management, 13, 69-84.

Barnes, A. (2011). Celebrity: Celebrity and food. Lifted Brow, The, 12, 6-7

Bekk, M. \& Spörrle, M. (2010).The Influence of Perceived Personality Characteristics on Positive Attitude towards and Suitability of a Celebrity as a Marketing Campaign Endorser. Open Psychology Journal, $3(1), 54-66$.

Belaid, S. \& T. Behi, A. (2011). The role of attachment in building consumer-brand relationships: an empirical investigation in the utilitarian consumption context. Journal of Product \& Brand Management, 20(1), 37-47.

Berry, L. L. (2000). Cultivating service brand equity. Journal of the Academy of marketing Science, 28(1), 128137.

Biscaia, R., Correia, A., Rosado, A. F., Ross, S. \& Maroco, J. (2013). Sport sponsorship: The relationship between team loyalty, sponsorship awareness, attitude toward the sponsor, and purchase intentions. Journal of Sport Management, 27, 288-302. 
Chi, H. K., Yeh, H. R. \& Yang, Y. T. (2009). The impact of brand awareness on consumer purchase intention: The mediating effect of perceived quality and brand loyalty. Journal of International Management Studies, 4(1), 135-144.

Choi, S. \& Rifon, N. J. (2007). Who is the celebrity in advertising? Understanding dimensions of celebrity images. The journal of popular Culture, 40(2), 304-324.

Clark, C. R., Doraszelski, U. \& Draganska, M. (2009). The effect of advertising on brand awareness and perceived quality: An empirical investigation using panel data. QME 7, 2, 207-236.

Collins, H. (2010). Creative research: the theory and practice of research for the creative industries. Ava Publishing.

Conner, M. \& Armitage, C. J. (1998). Extending the theory of planned behaviour: A review and avenues for further research. Journal of applied social psychology, 28(15), 1429-1464.

Costanzo, P. J. \& Goodnight, J. E. (2006). Celebrity endorsements: Matching celebrity and endorsed brand in magazine advertisements. Journal of Promotion Management, 11(4), 49-62.

Daniel, J. (2011). Sampling essentials: Practical guidelines for making sampling choices. London, UK: Sage.

Ding, H., Molchanov, A. E. \& Stork, P. A. (2011). The value of celebrity endorsements. A stock market perspective. Marketing letter, 22, 147-163.

Dix, S., Phau, I. \& Pougnet, S. (2010). Bend it like Beckham": the influence of sports celebrities on young adult consumers. Young Consumers, 11(1), 36-46.

Erdogan, B. Z., Baker, M. J. \& Tagg, S. (2001). Selecting celebrity endorsers: The practitioner's perspective. Journal of advertising research, 41(3), 39-48.

Erfgen, C., Zenker, S. \& Sattler, H. (2015). The vampire effect: When do celebrity endorsers harm brand recall? International Journal of Research in Marketing, 32(2), 155-163.

Fagarasanu, M. \& Kumar, S. (2002). Measurement instruments and data collection: a consideration of constructs and biases in ergonomics research. International Journal of Industrial Ergonomics, 30(6), 355-369.

Francis, J. J., Eccles, M. P., Johnston, M., Walker, A., Grimshaw, J., Foy, R. \& Bonetti, D. (2004). Constructing questionnaires based on the theory of planned behaviour. A manual for health services researchers, 2 , $2-12$.

Fraering, M. \& Minor, M. S. (2006). Sense of Community: An Exploratory Study of US Consumers of Financial Services. International Journal of Bank Marketing, 24(5), 284-306.

Han, W. \& Rashad Yazdanifard, 0. (2015).The Review of the Effectiveness of Celebrity Advertising that Influence Consumer's Perception and Buying Behavior. Global Journal of Management and Business Research, 15(4), 23-29.

Galpin, J. S. (2011). Statistical research design and analysis. [Lecture notes]. Johannesburg, South Africa: University of the Witwatersrand, School of Statistics and Actuarial Science.

Henle, C. A., Reeve, C. L. \& Pitts, V. E. (2010).Stealing time at work: Attitudes, social pressure, and perceived control as predictors of time theft. Journal of Business Ethics, 94(1), 53-67.

Hollebeek, L. D., Jaeger, S. R., Brodie, R. J. \& Balemi, A. (2007).The influence of involvement on purchase intention for new world wine. Food Quality and Preference, 18(8), 1033-1049.

Huang, R. \& Sarigöllü, E. (2012). How brand awareness relates to market outcome, brand equity, and the marketing mix. Journal of Business Research, 65(1), 92-99.

Hudders, L., Cauberghe, V., Panic, K., Faseur, T. \& Zimmerman, E. (2012). Brand placement in music videos: the effect of brand prominence and artist connectedness on brand recalls and brand attitude. In 11th International conference on Research in Advertising (ICORIA 2012): The changing roles of advertising.

Illicic, J. \& Webster, C. M. (2011). Effects of multiple endorsements and consumer-celebrity attachment on attitude and purchase intention. Australasian Marketing Journal (AMJ), 19(4), 230-237.

Keller, K. L. (2008). Strategic branding management building, measuring and managing brand equity 3ed. Upper saddle River, New Jersey. Prentice Hall.

Kim, S. S., Lee, J., \& Prideaux, B. (2014). Effect of celebrity endorsement on tourists' perception of corporate image, corporate credibility and corporate loyalty. International Journal of Hospitality Management, 37, 131-145.

Koernig, S. K. \& Boyd, T. C. (2009). To Catch a Tiger or Let Him Go: The Match-up Effect and Athlete Endorsers for Sport and Non-Sport Brands. Sport Marketing Quarterly, 18(1), 15-37. 
Liu, F., LI, J., Mizerki, D. \& Soh, H. (2012). Self-congruity, brand attitude, and brand loyalty: A study on luxury brands. European Journal of Marketing, 46(7/8), 922-937.

Lu, L. C., Chang, W. P. \& Chang, H. H. (2014). Consumer attitudes toward blogger's sponsored recommendations and purchase intention: The effect of sponsorship type, product type, and brand awareness. Computers in Human Behaviour, 34, 258-266.

Macdonald, E. K. \& Sharp, B. M. (2000). Brand awareness effects on consumer decision making for a common, repeat purchase product: A replication. Journal of business research, 48(1), 5-15.

Malik, A. \& Sudhakar, B. D. (2014). Brand positioning through celebrity Endorsement- A review contribution to brand literature. International Review of Management and Marketing, 4(4), 259-275.

Muda, M., Musa, R. \& Putit, L. (2012). Breaking through the Clutter in Media Environment: How Do Celebrities Help? Procedia-Social and Behavioral Sciences, 42, 374-382.

Patel, P. C. (2009). Impact of Celebrity Endorsement on Brand Acceptance. ICFAI Journal of Consumer Behaviour, 4(1), 36-45.

Pedeliento, G., Andreini, D., Bergamaschi, M. \& Salo, J. (2015). Brand and product attachment in an industrial context: The effects on brand loyalty. Industrial Marketing Management.

Petty, R. D. \& D'Rozario, D. (2009). The use of dead celebrities in advertising and marketing: balancing interests in the right of publicity. Journal of advertising, 38(4), 37-49.

Petzer, D., Mostert, P., Kruger, L. M. \& Kuhn, S. (2014). The dimensions of brand romance as predictors of brand loyalty among cell phone users. South African Journal of Economic and Management Sciences, 17(4), 457-470.

Ranjbarian, B., Shekarchizade, Z. \& Momeni, Z. (2010). Celebrity endorser influence on attitude toward advertisements and brands. European Journal of Social Sciences, 13(3), 399-407.

Rauyruen, P. \& Miller, K. E. (2007).Relationship quality as a predictor of B2B customer loyalty. Journal of business research, 60(1), 21-31

Rawtani, K. J. (2010). Celebrity endorsements and brand building. India. MBA- IB: 1-88

Rodriguez, K. P. (2009). Apparel brand endorsers and their effects on purchase intentions: a study of Philippine consumers. Philippine Management Review, 15, 83-99

Rossiter, J. R. \& Percy, L. (1997). Advertising communications \& promotion management (2nd Ed.). New York: McGraw-Hill Company.

Sajan, K. V. \& Nehru, S. (2014). Effectiveness of celebrity endorsement on brand recognition with special reference to Trivandrum city Kerala. Conference paper

Sheu, J. B. (2010). A hybrid dynamic forecast model for analyzing celebrity endorsement effects on consumer attitudes. Mathematical and Computer Modelling, 52(9), 1554-1569.

Sliburyte, L. (2009). How celebrities can be used in advertising to the best advantage. World Academy of Science, Engineering and Technology, 58(2), 934-939.

Tan, B. (2002). Understanding consumer ethical decision making with respect to purchase of pirated software. Journal of consumer marketing, 19(2), 96-111.

Tsai, S. P. (2011). Fostering international brand loyalty through committed and attached relationships. International Business Review, 20(5), 521-534.

Valkenburg, P. M. \& Buijzen, M. (2005). Identifying determinants of young children's brand awareness: Television, parents, and peers. Journal of Applied Developmental Psychology, 26(4), 456-468.

Wang, Y. \& Song, Y. (2013). Counterfeiting: Friend or Foe of Luxury Brands? An Examination of Chinese Consumers' Attitudes toward Counterfeit Luxury Brands. Journal of Global Marketing, 26(4), 173187.

Wang, Y. (2014). Consumers' Purchase Intentions of Shoes: Theory of Planned Behaviour and Desired Attributes. International Journal of Marketing Studies, 6(4), 50-58

Wee, T. T. T. \& Ming, M. C. H. (2003). Leveraging on symbolic values and meanings in branding. Journal of Brand Management, 10, 208-218.

Wei, P. S. \& Lu, H. P. (2013). An examination of the celebrity endorsements and online customer reviews influence female consumers' shopping behaviour. Computers in Human Behaviour, 29(1), 193-201.

White, D. W., Goddard, L. \& Wilbur, N. (2009). The effects of negative information transference in the celebrity endorsement relationship. International Journal of Retail \& Distribution Management, 37(4), 322-335. 